\title{
KAJIAN STRATEGI PENGENDALIAN PENCEMARAN SUB DAERAH ALIRAN SUNGAI (DAS) KALI DENDENG KOTA KUPANG
}

\author{
THE STUDY OF WATERSHED POLLUTION CONTROL \\ STRATEGY IN KALI DENDENG KUPANG CITY \\ Philiphi de Rozari \\ Jurusan Kimia Fakultas Sains Dan Teknik Universitas Nusa Cendana \\ Phderozari@yahoo.com
}

\begin{abstract}
Abstrak
Keberadaan Kali Dendeng menjadi sangat vital bagi warga kota Kupang karena air yang berasal dari sungai digunakan oleh masyarakat untuk berbagai keperluan baik domestik, pertanian, peternakan dan industri kecil. Penetapan status badan air Kali Dendeng memerlukan upaya pengendalian kualitas air karena kualitas air yang menurun dapat menjadi permasalahan tersendiri terhadap nilai ekonomi air sebagai sumber air bersih, kesehatan masyarakat, dan kehidupan ekologis biota air. Penelitian ini bertujuan untuk; (1) menentukan kondisi eksisting fisik dan kimia perairan Kali Dendeng dan menganalisis kualitas perairan Kali Dendeng serta menentukan beban pencemanran menurut beberapa paramenter kualitas air berdasarkan parameter kualitas air; (2) mengidentifikasi sumber dan jenis pencemar di dalam air limbah dan air sungai; (3) mengidentifikasi perilaku masyarakat di sekitar Kali Dendeng dalam membuang air limbah serta memanfaatkan sumberdaya air di Kali Dendeng; (4) mengidentifikasi peran berbagai stakeholder baik pemerintah maupun masyarakat di sekitar Kali Dendeng dalam mewujudkan keberlajutan pemanfaatan, pengelolaan dan perlindungan terhadap sumberdaya air di Kali Dendeng. Penelitian dilaksanakan dengan mengukur langsung beberapa parameter kualitas air seperti kekeruhan, konduktivitas, $\mathrm{pH}, \mathrm{DO}, \mathrm{COD}, \mathrm{BOD}, \mathrm{TSS}, \mathrm{N}-\mathrm{Nitrit}, \mathrm{P}_{-} \mathrm{PO}_{4}{ }^{3-}$, minyak dan lemak, detergen serta bakteri coliform dan mendistribusikan kuisioner kepada warga yang tinggal di sempadan sungai di Sub DAS Kali Dendeng. Hasil penelitian menunjukkan bahwa kadar BOD, minyak dan lemak, dan coliform di sub DAS Kali Dendeng telah melebihi ambang batas yang ditetapkan sesuai dengan PP No.82 Tahun 2001. Selain itu, status kualitas air dengan mengunakan STORET analisis menunjukkan bahwa sub DAS Kali Dendeng dikategorikan tercemar sedang dengan beban BOD $=29,448 \mathrm{~kg} /$ hari dan beban COD $=56,540 \mathrm{~kg} / \mathrm{hari}$. Sumber pencemar umumnya berasal dari sampah, limbah cair buangan baik dari septik maupun greywater, buangan limbah industri tahu, dan limbah peternakan babi.
\end{abstract}

Kata kunci: Kali Dendeng, Daerah Aliran Sungai, Kualitas Air, Pencemaran. 


\begin{abstract}
Kali Dendeng is important river for Kupang citizen because the water resources from Kali Dendeng are used by the communities for domestic, agriculture, animal husbandry and small industries purposes. This research aims to; (1) to determine the physical and chemical condition of the waters of Kali Dendeng and to analyze the water quality of Kali Dendeng River and to determine the load of the pollutant based on several water quality parameters; (2) to identify sources and types of pollutants in wastewater and river water; (3) to identify the role of various stakeholders in Kali Dendeng to achieve sustainable use of water resources and to protect the environment. The study was conducted by measuring several water quality parameters such as turbidity, conductivity, $p H, D O, C O D, B O D, T S S, N-$ Nitrite, P-PO43-, oils and fats, detergents and coliform bacteria in several sampling points and distributing questionnaires to decision makers and communities living in Kali Dendeng River Basin. The results showed that BOD, oil and fat, and coliform concentrations in Kali Dendeng had exceeded the threshold specified in accordance with Government Regulation No.82 of 2001. In addition, water quality status using STORET INDEX analysis showed that sub $D A S$ Kali Dendeng was categorized medium contaminated with BOD load = $29,448 \mathrm{~kg} /$ day and COD load $=56,540 \mathrm{~kg} /$ day. The waste disposal from septic or greywater, disposal of tofu industry waste, and pig farm waste was the major contribution of water pollution in Kali Dendeng.
\end{abstract}

Keywords: Kali Dendeng, Watershed, Water Quality, Pollution.

\title{
PENDAHULUAN
}

Selama dua dekade ini, jumlah negara berkembang yang mengalami kelangkaan ketersediaan sumber daya air meningkat secara signifikant. Umumnya negara negara ini terletak di daerah tropis. Salah satu faktor penyebab kelangkaan air adalah meningkatnya pencemaran air. Tendensi pencemaran air ini disebabkan oleh bebarapa faktor antara lain peningkatan populasi penduduk, peningkatan industrialisasi dan arus urbanisasi di perkotaan (Kansiime and Nelubega, 1999; Kivaisi, 2001).

Konsumsi air di Indonesia mempunyai kencederungan naik secara eksponensial sementara ketersediaan air bersih terus berkurang dengan cepat akibat kerusakan alam dan pencemaran yang diperkirakan sebesar 15-35\% per kapita per tahun (KLH, 2009). Pencemaran air ini terjadi pada danau, sungai, mata air dan air tanah. Air limbah domestik merupakan kontributor pencemaran air yang terbesar di Indonesia diikuti dengan air limbah yang berasal dari kegiatan industri dan pertanian (USAID, 2006). Kurniadi (2011) melaporkan bahwa 75\% air limbah domestik yang dibuang ke badan air tidak melalui proses treatment. Hal ini menunjukkan bahwa hanya sekitar 25\% dari air limbah domestik yang ditangani sebelum dibuang ke badan air.

Kota Kupang yang merupakan ibu kota Provinsi Nusa Tenggara Timur (NTT) adalah salah satu kota yang juga mengalami permasalahan pencemaran air. Jumlah penduduk yang terus meningkat dan arus urbanisasi merupakan faktor yang mempengaruhi proses terjadinya pencemaran air pada air permukaan dan air tanah di Kota Kupang. Luas area adminsitratif Kota Kupang adalah $180.27 \mathrm{~km}^{2}$ dan jumlah populasi penduduk pada tahun 2016 sebesar 402.286 jiwa (BPS Kota 
Kupang, 2017). Namun, peningkatan jumlah populasi ini tidak diikuti dengan peningkatan fasilitas sanitasi dan air bersih yang memadai. Saat ini, penanganan air limbah dengan sistem pembuangan yang terintegrasi dengan pola penanganan air limbah yang terpusat belum dapat dilakukan. Hal ini disebabkan karena besarnya biasa inventasi, operasional dan pemeliharaan fasilitas pengolahan air limbah yang terpadu (integrated wastewater treatment system). Umumnya masyarakat yang mendiami bantaran sungai langsung membuang air limbahnya di sungai dan sumber air lainnya. Hal ini menyebabkan sungai, danau dan mata air yang digunakan sebagai sumber air bersih untuk perkotaan menjadi tercemar.

Kali Dendeng merupakan salah satu dari 35 sungai penting di Indonesia. Air Kali Dendeng dimanfaatkan untuk berbagai kebutuhan, termasuk untuk mensuplai air bersih pada masyarakat Kota Kupang yang pendistribusiannya kepada warga masyarakat dilakukan oleh PDAM Kota Kupang. Bebererapa anak sungai yang bermuara pada kali Dendeng antara lain Kali Mapoli, Kapadala, Airnona, Bakunase dan Kali Sembunyi. Kali Dendeng mempunyai luas daerah aliran sungai sebesar $47.73 \mathrm{~km}^{2}$ dan panjang sekitar $11.8 \mathrm{~km}$ (BAPEDALDA, 2005). Pesatnya perkembangan Kota Kupang berdampak pada terjadinya perubahan penggunaan lahan di sepanjang Kali Dendeng yang semula berupa kawasan hutan berubah menjadi kawasan pemukiman. Kondisi ini menyebabkan berkurangnya kawasan jalur hijau di sekitar Kali Dendeng. Bertambahnya aktifitas masyarakat di sekitar Kali Dendeng menimbulkan dampak negatif terhadap kuantitas dan kualitas air pada Kali Dendeng. Keberadaan Kali Dendeng sangat vital bagi warga kota Kupang karena sumber air sungai ini berfungsi sebagai salah satu sumber daya air bagi masyarakat Kota Kupang. Untuk itu diperlukan upaya pengendalian kualitasnya dengan menetapkan besar limbah yang boleh dibuang ke badan air sungai itu disesuaikan dengan debit air sungai yang ada. Kualitas air yang terus menurun menjadi permasalahan tersendiri terhadap nilai ekonomi air sebagai sumber air bersih, kesehatan masyarakat, dan kehidupan ekologis biota air.

Permaasalahan pengendalian pencemaran air sungai umumnya bersifat kompleks, dinamik karena terkait dengan multistakeholder. Oleh karena itu, pengendalian pencemaran air Kali Dendeng membutuhkan pendekatan kepada stakeholder secara menyeluruh. Berdasarkan latar belakang diatas maka dapat dirumuskan sebagai berikut: (1) Bagaimana kondisi existing kualitas air Kali Dendeng dilihat dari parameter fisika, kimia dan biologi?, dan (2) Bagaimana peran berbagai stakeholder baik pemerintah maupun masyarakat di sekitar Kali Dendeng dalam mewujudkan keberlajutan pemanfaatan, pengelolaan dan perlindungan terhadap sumberdaya air di Kali Dendeng? Tujuan penelitan ini adalah untuk (1) menentukan kondisi eksisting fisik dan kimia perairan Kali Dendeng dan menganalisis kualitas perairan Kali Dendeng serta menentukan beban pencemaran menurut beberapa parameter kualitas air berdasarkan parameter kualitas air; dan (2) mengidentifikasi peran berbagai stakeholder baik pemerintah maupun masyarakat di sekitar Kali Dendeng dalam mewujudkan keberlajutan pemanfaatan, pengelolaan dan perlindungan terhadap sumberdaya air di Kali Dendeng. 


\section{METODE PENELITIAN}

\section{Waktu dan Tempat Penelitian}

Penelitian dilakukan di Sub DAS Kali Dendeng selama bulan Juli sampai dengan Oktober 2017 dan terdiri atas dua tahap. Tahap pertama adalah menentukan kondisi eksisting perairan Kali Dendeng terhadap parameter fisikkimia dan biologi mencakup: pH, suhu, TDS, DHL, TSS, DO, BOD, COD, Mn, $\mathrm{Fe}, \mathrm{Cd}, \mathrm{Pb}, \mathrm{Zn}$, detergen, minyak dan lemak, sulfat, phospat, nitrit, faecal coliform dan total coliform. Selain itu pada tahapan ini dilakukan pula identifikasi terhadap sumber sumber pencemar dan beban pencemar terhadap beberapa parameter. Tahap kedua mengidentifikasi peran berbagai stakeholder dalam mewujudkan keberlanjutan pemanfaatan, pengelolaan dan perlindungan terhadap sumberdaya air di Daerah Aliran Sungai Kali Dendeng. Lokasi pengambilan sampel di Sub DAS Kali Dendeng tercatat pada Tabel 1.

Table 1 Lokasi Pengambilan Sampel di DAS Kali Dendeng

\begin{tabular}{|l|l|l|l|}
\hline No & Nama Sampel & Lokasi & Koordinat \\
\hline 1 & Stasiun 1 & Kali Biknoi & $\begin{array}{l}\text { S: } 10^{\circ} 13^{\prime} 52.74^{\prime \prime} \\
\text { E: } 123^{\circ} 36^{\prime} 18.18^{\prime \prime}\end{array}$ \\
\hline 2 & Stasiun 2 & Kali Bakunase 2 & $\begin{array}{l}\text { S: } 10^{\circ} 11^{\prime} 07.03^{\prime \prime} \\
\text { E: } 123^{\circ} 35^{\prime} 49.35^{\prime \prime}\end{array}$ \\
\hline 3 & Stasiun 3 & Kali Airnona & $\begin{array}{l}\text { S: } 10^{\circ} 10^{\prime} 58.90^{\prime \prime} \\
\text { E: } 123^{\circ} 34^{\prime} 47.81^{\prime \prime}\end{array}$ \\
\hline 4 & Stasiun 4 & Kali Sembunyi & $\begin{array}{l}\text { S: } 10^{\circ} 10^{\prime} 32.57^{\prime \prime} \\
\text { E: } 123^{\circ} 35^{\prime} 25.39^{\prime \prime}\end{array}$ \\
\hline 5 & Stasiun 5 & $\begin{array}{l}\text { Intake Bendung Kali } \\
\text { Dendeng }\end{array}$ & $\begin{array}{l}\text { S: } 10^{\circ} 10^{\prime} 22.44^{\prime \prime} \\
\text { E: } 123^{\circ} 35^{\prime} 00.69^{\prime \prime}\end{array}$ \\
\hline 6 & Stasiun 6 & Bendung Kali Dendeng 2 & $\begin{array}{l}\text { S: } 10^{\circ} 10^{\prime} 15.91^{\prime \prime} \\
\text { E: } 123^{\circ} 34^{\prime} 58.73^{\prime \prime}\end{array}$ \\
\hline 7 & Stasiun 7 & Jembatan Bakunase & $\begin{array}{l}\text { S: } 10^{\circ} 11^{\prime} 30.30^{\prime \prime} \\
\text { E: } 123^{\circ} 35^{\prime} 03.20^{\prime \prime}\end{array}$ \\
\hline
\end{tabular}

Penelitian ini didasarkan atas du jenis data yakni data primer dan data sekunder. Pengumpulan data primer dilakukan melalui survei lapangan serta pengukuran in situ dan analisis di laboratorium terhadap parameter fisik, kimia, biologi dan variasi debit air Kali Dendeng serta wawancara dengan para pengambil keputusan dan warga masyarakat masyarakat yang tinggal di sekitar DAS Kali Dendeng. Data primer tentang kondisi fisik dan kimia perairan serta sumber dan jenis pencemar dalam limbah dan air sungai diperoleh di lapangan dan dari hasil analisis laboratorium. Data primer mengenai peran berbagai stakeholder dalam mewujudkan keberlanjutan pemanfaatan, pengelolaan dan perlindungan terhadap sumberdaya air DAS Kali Dendeng diperoleh melalui wawancara mendalam (in-depth interview) dengan para pengambil keputusan. Sampel diambil di dua belas kelurahan yang dilintasi DAS Kali Dendeng. Data sekunder yang dikumpulkan melalui studi dokumen meliputi jumlah penduduk, dan industri kecil. Data beban limbah diperoleh melalui pengukuran konsentrasi parameter beban limbah pada setiap stasiun/titik pengamatan dan debit limbah. 


\section{Metode Pengumpulan Data:Analisis Laboratorium}

Analisis laboratorium dilakukan terhadap contoh air di DAS Kali Dendeng menggunakan metode yang diadopsi dari American Public Health Assocoation (APHA, 1998) seperti ditunjukkan pada Tabel 2.

Tabel 2. Parameter Kualitas Air Dan Acuan Metode Analisis Yang Digunakan

\begin{tabular}{|l|c|l|l|}
\hline Parameter & Satuan & Acuan Metode & Metode \\
\hline I. Fisika & & & \\
1. Suhu & ${ }^{\circ} \mathrm{C}$ & SNI 06-6989.23-2005 & Thermometri \\
2. TDS & $\mathrm{mg} / \mathrm{L}$ & SNI 06-6989.1-2004 & Konduktometri \\
3. DHL & $\mu \mathrm{S} / \mathrm{cm}$ & SNI 06-6989.1-2004 & Konduktometri \\
4. TSS & $\mathrm{mg} / \mathrm{L}$ & SNI 06-6989.3-2004 & Gravimetri \\
& & & \\
II. Kimia dan biologi & & & \\
1. pH & - & SNI 06-6989.11-2004 & pHmeter \\
2. DO & $\mathrm{mg} / \mathrm{L}$ & SNI 06-6989.14-2004 & Iodometri \\
3. COD & $\mathrm{mg} / \mathrm{L}$ & SNI 6989.2-2009 & Spektrofotometri \\
4. BOD & $\mathrm{mg} / \mathrm{L}$ & SNI 6989.72-2009 & DO meter \\
5. N-Nitrit & $\mathrm{mg} / \mathrm{L}$ & SNI 06-6989.9-2004 & Spektrofotometri \\
6. Fosfat & $\mathrm{mg} / \mathrm{L}$ & SNI 06-6989.31-2005 & Spektrofotometri \\
7. Sulfat & $\mathrm{mg} / \mathrm{L}$ & SNI 06-6989.20-2004 & Turbidimetri \\
8.Minyak dan lemak & $\mu \mathrm{g} / \mathrm{L}$ & JIS K 0102-24 & Gravimetri \\
9. Detergen & $\mu \mathrm{g} / \mathrm{L}$ & SNI 06-6989.51-2005 & Spektrofotometri \\
10. Mangan & $\mathrm{mg} / \mathrm{L}$ & SNI 6989.5-2009 & Spektrofotometri AAS \\
11. Besi & $\mathrm{mg} / \mathrm{L}$ & SNI 6989.4-2009 & Spektrofotometri AAS \\
12. Kadmium & $\mathrm{mg} / \mathrm{L}$ & SNI 6989.16-2009 & Spektrofotometri AAS \\
13. Tembaga & $\mathrm{mg} / \mathrm{L}$ & SNI 6989.6-2009 & Spektrofotometri AAS \\
15. Seng & $\mathrm{mg} / \mathrm{L}$ & SNI 6989.7-2009 & Spektrofotometri AAS \\
16.Total coliforms & $\mathrm{MPN}$ & SNI 06-2421-1991 & Colony counter \\
17. Feacal coliform & $\mathrm{MPN}$ & SNI 06-2421-1991 & Colony counter \\
\hline
\end{tabular}

\section{Metode Pengumpulan Data: Analisis Stakeholder}

Analisis kebutuhan merupakan tahap awal untuk mengidentifikasi beragam kebutuhan dari setiap pelaku/stakeholders (Hartrisari, 2007). Setiap pelaku sistem memiliki kebutuhan berbeda yang dapat mempengaruhi kinerja sistem. Analisis sistem pengendalian pencemaran air Kali Dendeng melibatkan beberapa pelaku yang terlibat dalam sistem tersebut. Pelaku yang terlibat dalam sistem pengendalian pencemaran air Kali Dendeng meliputi: Masyarakat di sekitar sungai, pemerintah daerah (BPLHD dan PU Pengairan, Kelurahan dan Kecamatan), Perguruan Tinggi, PDAM Kota Kupang, dan industri kecil.

\section{Penentuan Kualitas Perairan Kali Dendeng}

Metode yang digunakan untuk menentukan kualitas perairan atau status mutu air Kali Dendeng adalah metode STORET (Storage and Retrieval of Water Quality Data System). Melalui metode STORET data parameter kualitas air hasil pengukuran dibandingkan dengan baku mutu air sesuai PP Nomor 82 Tahun 2001. 
Penentuan status mutu air dengan metode STORET adalah dengan menggunakan sistem nilai dari US-EPA (United State - Environmental Protection Agency), dengan mengklasifikasikan mutu air dalam empat kelas, yaitu :

(1) Kelas A : baik sekali, skor $=0 \rightarrow$ memenuhi baku mutu

(2) Kelas B : baik, skor $=-1 \mathrm{~s} / \mathrm{d}-10 \rightarrow$ tercemar ringan

(3) Kelas C : sedang, skor $=-11 \mathrm{~s} / \mathrm{d}-30 \rightarrow$ tercemar sedang

(4) Kelas D : buruk, skor $\geq-31 \rightarrow$ tercemar berat

Langkah-langkah yang dilakukan untuk penentuan status kualitas air dengan metode Storet adalah:

1. Melakukan tabulasi data kualitas air yang memuat semua nilai hasil pengukuran parameter fisika dan kimia (kecerahan, kekeruhan, konduktivitas, $\mathrm{pH}, \mathrm{DO}, \mathrm{COD}, \mathrm{BOD}, \mathrm{TSS}, \mathrm{N}-\mathrm{Nitrit}, \mathrm{P}_{-} \mathrm{PO}_{4}{ }^{3-}, \mathrm{Pb}, \mathrm{Cd}, \mathrm{Cu}$, $\mathrm{Zn}$, minyak dan lemak, dan detergen) sehingga membentuk data dari waktu ke waktu dan mencantumkan nilai maksimum, minimum, dan ratarata hasil pengukuran tiap parameter pada setiap lokasi pengamatan;

2. Membandingkan nilai minimum, maksimum, dan rata-rata hasil pengukuran dari masing-masing parameter air dengan nilai baku mutu yang sesuai dengan kelas air;

3. Jika hasil pengukuran memenuhi nilai baku mutu (hasil pengukuran $\leq$ baku mutu) maka diberi skor 0 ;

4. Jika hasil pengukuran tidak memenuhi nilai baku mutu air (hasil pengukuran $>$ baku mutu), maka diberi skor:

\begin{tabular}{clcc}
\hline Jumlah Contoh*) & \multicolumn{1}{c}{ Nilai } & \multicolumn{2}{c}{ Parameter } \\
\cline { 3 - 4 } & & Fisika & Kimia \\
\hline \multirow{3}{*}{$<10$} & Maksimum & -1 & -2 \\
& Minimum & -1 & -2 \\
& Rata-rata & -3 & -6 \\
\hline \multirow{3}{*}{$\geq 10$} & Maksimum & -2 & -4 \\
& Minimum & -2 & -4 \\
& Rata-rata & -6 & -12 \\
\hline \multirow{2}{*}{ *) Jumlah parameter yang digunakan dalam menentukan status mutu air }
\end{tabular}

*) Jumlah parameter yang digunakan dalam menentukan status mutu air

5. Jumlah negatif dari seluruh parameter dihitung dan ditentukan status kualitasnya dari jumlah skor yang didapat dengan menggunakan sistem nilai.

\section{Analisis Beban Pencemaran}

Metode pengumpulan data untuk mengidentifikasi sumber dan beban pencemaran adalah melalui analisis parameter pencemar (in situ dan laboratorium), pengukuran debit limbah, dan data sekunder jumlah penduduk. Sumber pencemar yang diidentifikasi adalah industri, pemukiman, dan hotel/rumah makan. Sumber pencemar industri adalah industri yang mengalirkan limbah ke Kali Dendeng. 
Analisis beban pencemaran dari berbagai sumber pencemar baik dari effluen air limbah industri kecil, limbah pemukiman, dan limbah peternakan yang masuk ke perairan Kali Dendeng dilakukan melalui pendekatan Rapid Assessment of Sources of Air, Water, and Land Pollution (WHO 1993). Beban pencemaran dihitung menggunakan persamaan (Soemarno 2007):

$$
\mathrm{BPA}=(\mathrm{CA}) \mathrm{j} \times(\mathrm{DA}) \times \mathrm{f}
$$

Keterangan: BPA = Beban pencemaran sebenarnya $(\mathrm{kg} /$ hari $)$

$(\mathrm{CA}) \mathrm{j}=$ Kadar sebenarnya unsur pencemar $\mathrm{j}(\mathrm{mg} / \mathrm{l})$

DA = Debit limbah cair/sungai (liter/detik)

$\mathrm{f} \quad=$ faktor konversi $=0,086$

\section{HASIL DAN PEMBAHASAN}

\section{Kondisi Existing Kualitas Air di Sub DAS Kali Dendeng.}

Kondisi eksisting kualitas air di Sub DAS Kali Dendeng digambarkan dengan tingkat konsentrasi beberapa parameter kualitas air yang diukur. Parameter-parameter ini terdiri atas parameter fisika, kimia dan biologi. Setiap parameter kualitas air yang diukur di lapangan dan laboratorium dibandingkan dengan baku mutu kualitas air yang mengacu pada PP No. 82 tahun 2001 tentang Pengelolaan Kualitas dan Pengendalian Pencemaran Air. Peraturan ini mengatur kualitas air sesuai dengan peruntukan air tersebut.

\section{Derajat Keasaman (pH)}

Pengukuran $\mathrm{pH}$ pada 7 titik sampel di Sub DAS Kali Dendeng menunjukkan bahwa nilai $\mathrm{pH}$ berkisar antara 7.1 - 7.9 (Gambar 1). Menurut PP No.82 Tahun 2001 nilai pH untuk peruntukan air kelas 2 berkisar antara $6-9$. Hal ini menunjukan bahwa kualitas air di Sub DAS Kali Dendeng masih berada pada kondisi yang aman untuk keperluan sebagai prasarana/sarana rekreasi air, pembudidayaan ikan air tawar, peternakan, air untuk mengairi tanaman. 


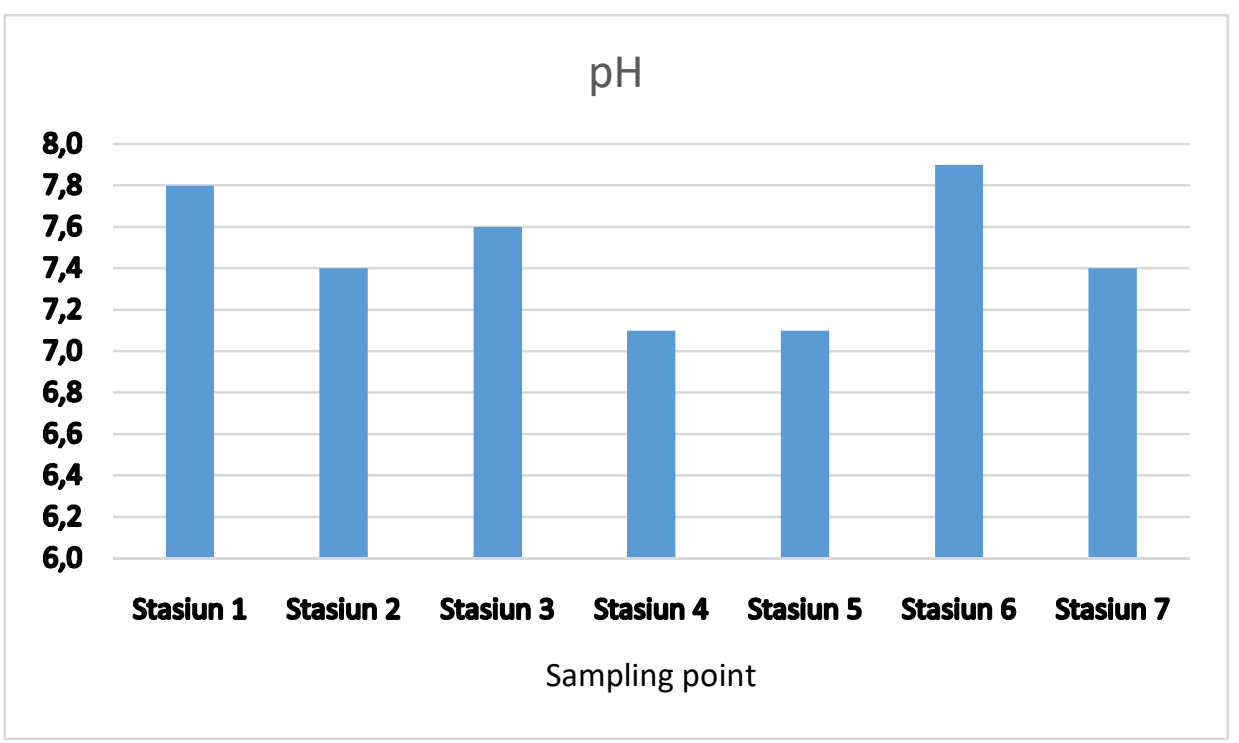

Gambar 1. Profil pH di tujuh titis sampel di Sub DAS Kali Dendeng

\section{Suhu}

Gambar 2 menunjukkan profil suhu pada tujuh titik sampel di Sub DAS Kali Dendeng. Hasil pengukuran menunjukkan bahwa suhu perairan pada Sub DAS Kali Dendeng berkisar antara $23-28^{\circ} \mathrm{C}$. Hal ini menunjukkan bahwa suhu perairan masih berada dibawah ambang batas yang ditetapkan untuk air golongan 2 menurut PP. No 82 Tahun 2001.

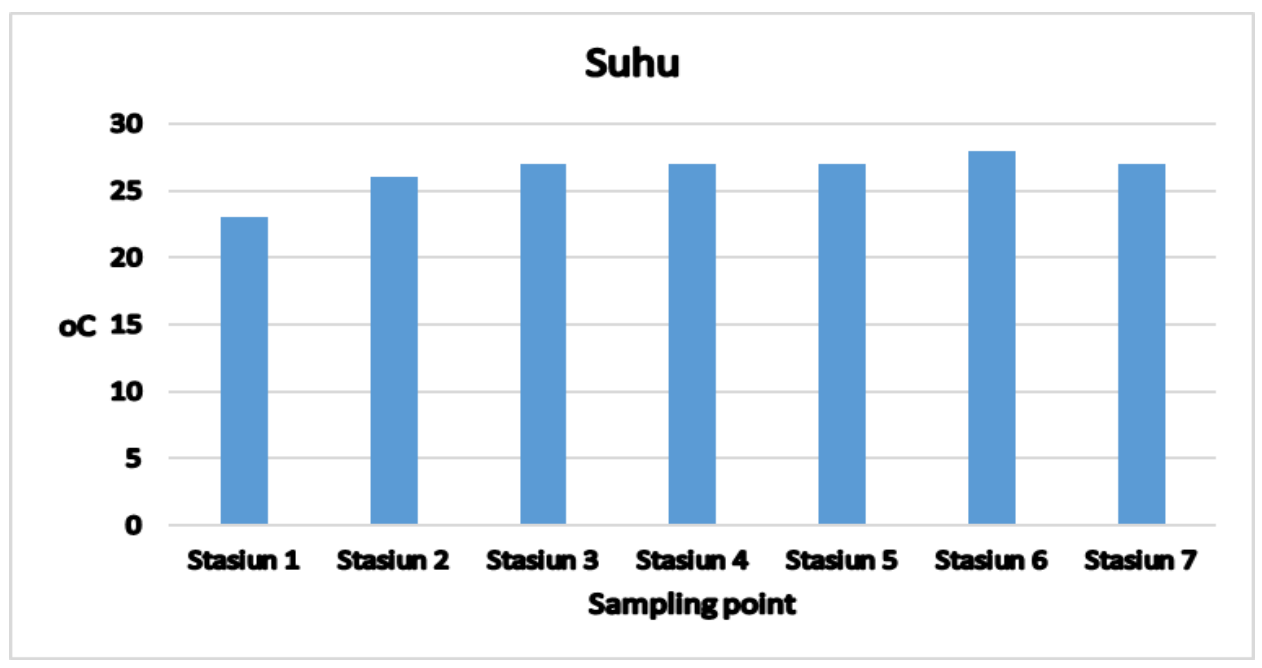

Gambar 2. Profil suhu $\left({ }^{\circ} \mathrm{C}\right)$ di tujuh titis sampel di Sub DAS Kali Dendeng

\section{Daya Hantar Listrik}

Nilai daya hantar listrik pada 7 titik sampel di Sub DAS Kali Dendeng berkisar antara $376-568 \mu \mathrm{S} / \mathrm{cm}$. DHL tertinggi berada pada Stasiun 4 di Kali Sembunyi dan terendah pada Stasiun 7 di Jembatan Bakunase. Gambar 3 memperlihatkan profil DHL $(\mu \mathrm{S} / \mathrm{cm})$ pada 7 titik sampel di sepanjang Sub DAS Kali Dendeng. 


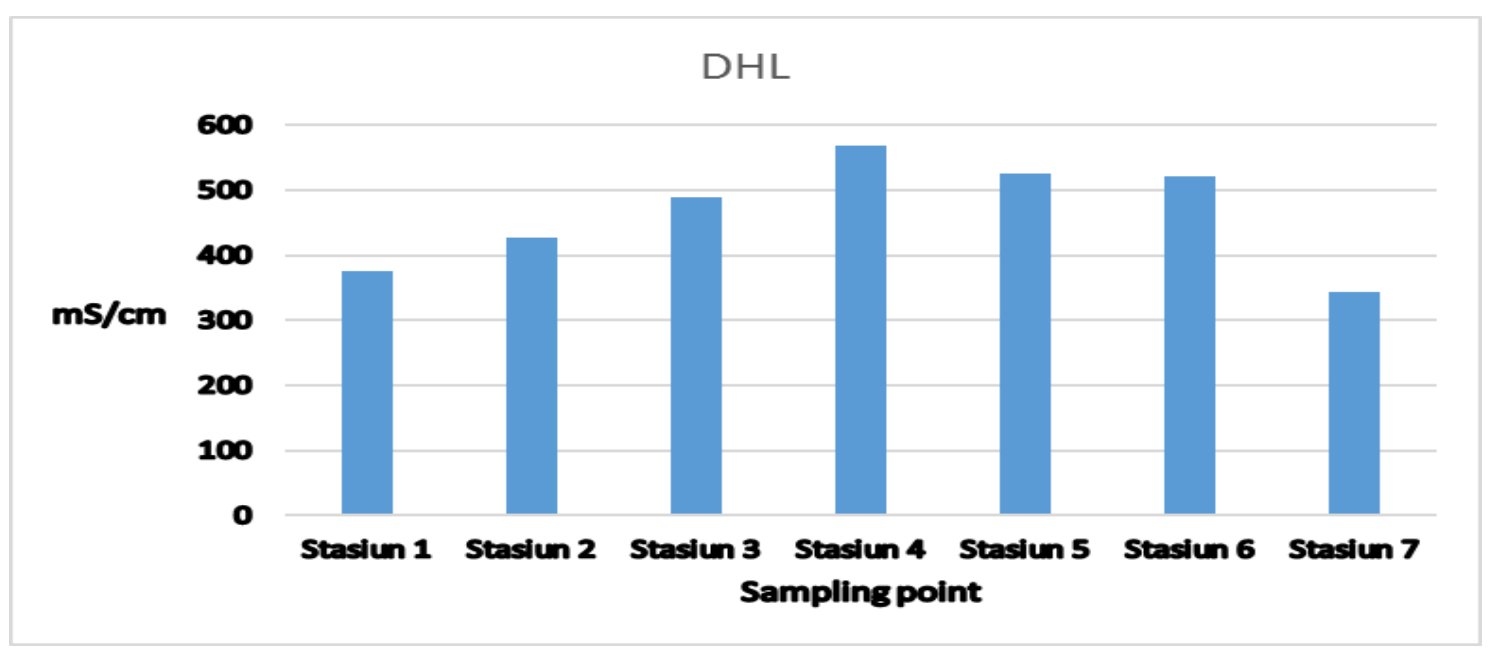

Gambar 3 Profil DHL $(\mu \mathrm{S} / \mathrm{cm})$ di tujuh titik sampel di Sub DAS Kali Dendeng

\section{Total Dissolved Solid (TDS) dan Total Suspended Solid (TSS)}

Hasil pengukurun TDS dan TSS di Sub DAS Kali Dendeng disajikan pada Gambar 4. Konsentrasi TDS pada 7 titik sampel di Sub DAS Kali Dendeng berkisar antara $189-301 \mathrm{mg} / \mathrm{L}$. Konsentrasi terendah berada pada Stasiun $7 \mathrm{di}$ Jembatan Bakunase dan tertinggi berada pada Stasiun 4 di Kali Sembunyi. Hasil pegukuran ini menunjukkan pula bahwa konsentrasi TDS pada sampel yang diambil pada 7 stasiun tersebut masih berada dibawah baku mutu air kelas II yang mensyaratkan konsentrasi TDS sebesar $1000 \mathrm{mg} / \mathrm{L}$.

Konsentrasi TSS (mg/L) pada 7 titik sampel di Sub DAS Kali Dendeng berkisar antara $1-15 \mathrm{mg} / \mathrm{L}$ (Gambar 4). Hasil ini masih dibawah baku mutu yang ditetapkan menurut PP No.82 Tahun 2001. Konsentrasi yang tertinggi berada pada titik sampling di Jembatan Bakunase (Stasiun 7) dan yang terendah di Stasiun 2 (Kali Bakunase). Kondisi ini diduga berasal dari limbah domestik dan limbah peternakan yang dibuang secara temporer ke dalam badan air di Sub DAS Kali Dendeng serta proses erosi yang terjadi di Sub DAS Kali Dendeng. Hal ini bisa menjadi peringatan bahwa Sub DAS Kali Dendeng rentan terhadap peningkatan konsentrasi TSS.

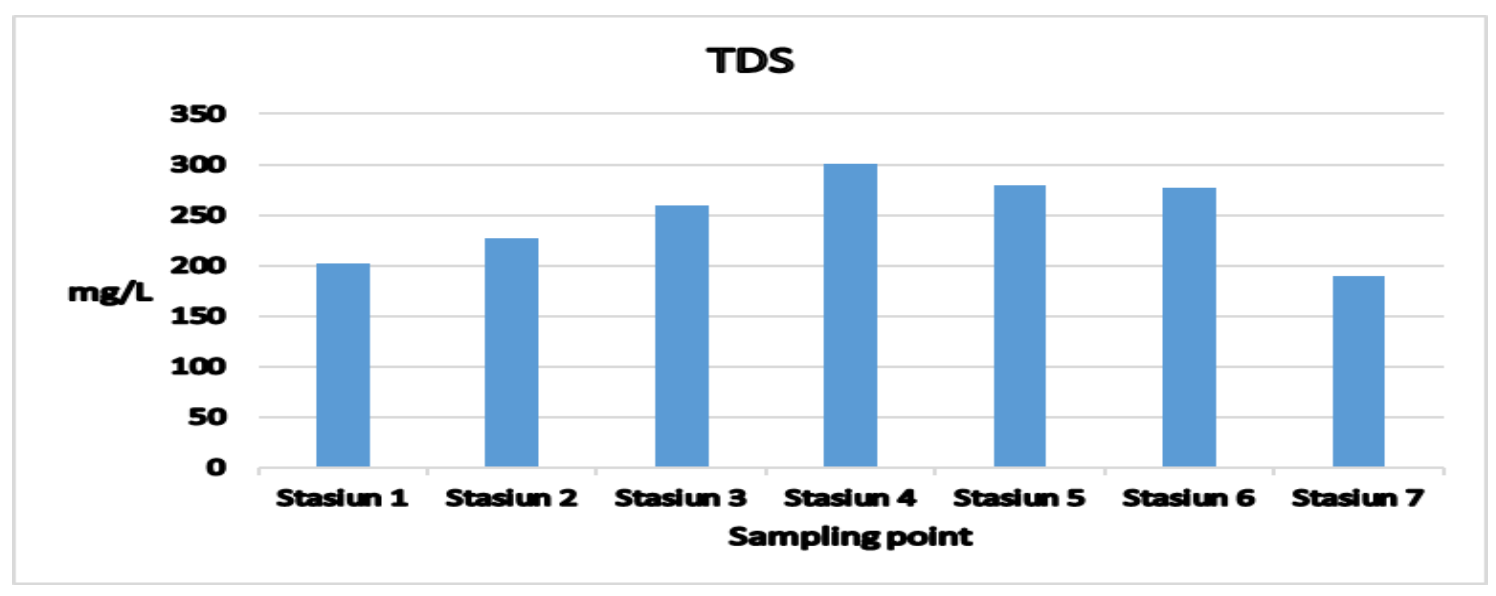




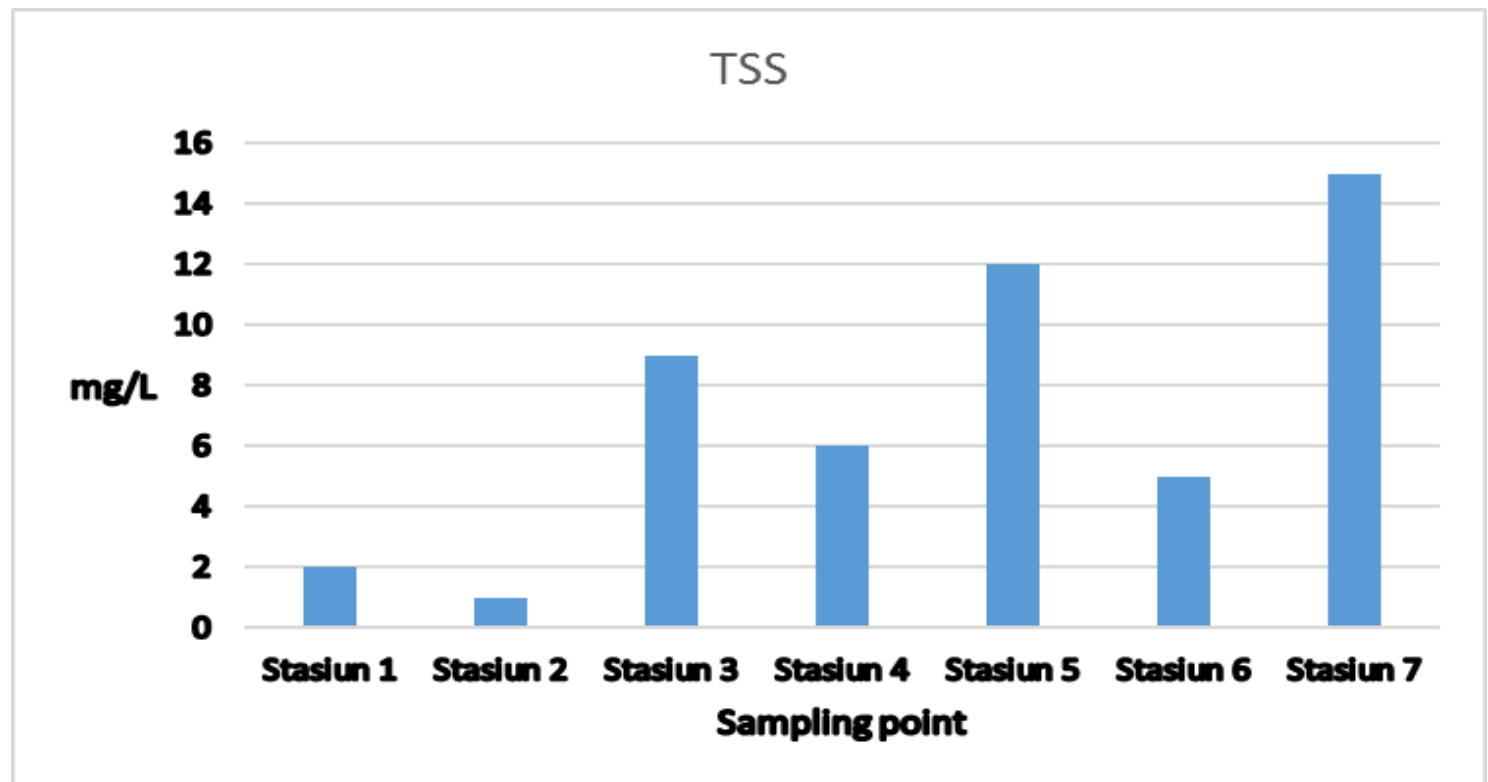

Gambar 4. Konsentrasi TDS dan TSS (mg/L) di tujuh titik sampel di Sub DAS

\section{Oksigen terlarut}

Kali Dendeng

Kadar oksigen terlarut di Sub DAS Kali Dendeng yang disampling pada bulan September berada pada kisaran 3,8-7,6 mg/L yang terlihat pada Gambar 5 . Kondisi ini menunjukan bahwa semua titik sampel yang diambil memenuhi baku mutu lingkungan kelas II karena limit konsentrasi oksigen terlarut pada baku mutu golongan adalah $>4 \mathrm{mg} / \mathrm{L}$. Namun data yang diperoleh dari hasil pemantauan Dinas Lingkungan Hidup Daerah Tahun 2014 - 2016 menunjukkan bahwa ada berapa stasiun yang diambil pada bulan bulan tertentu tidak memenuhi baku mutu. Kondisi ini patut menjadi perhatian bersama karena penurunan kadar oksigen terlarut dapat menyebabkan dampak negatif bagi mahluk hidup.

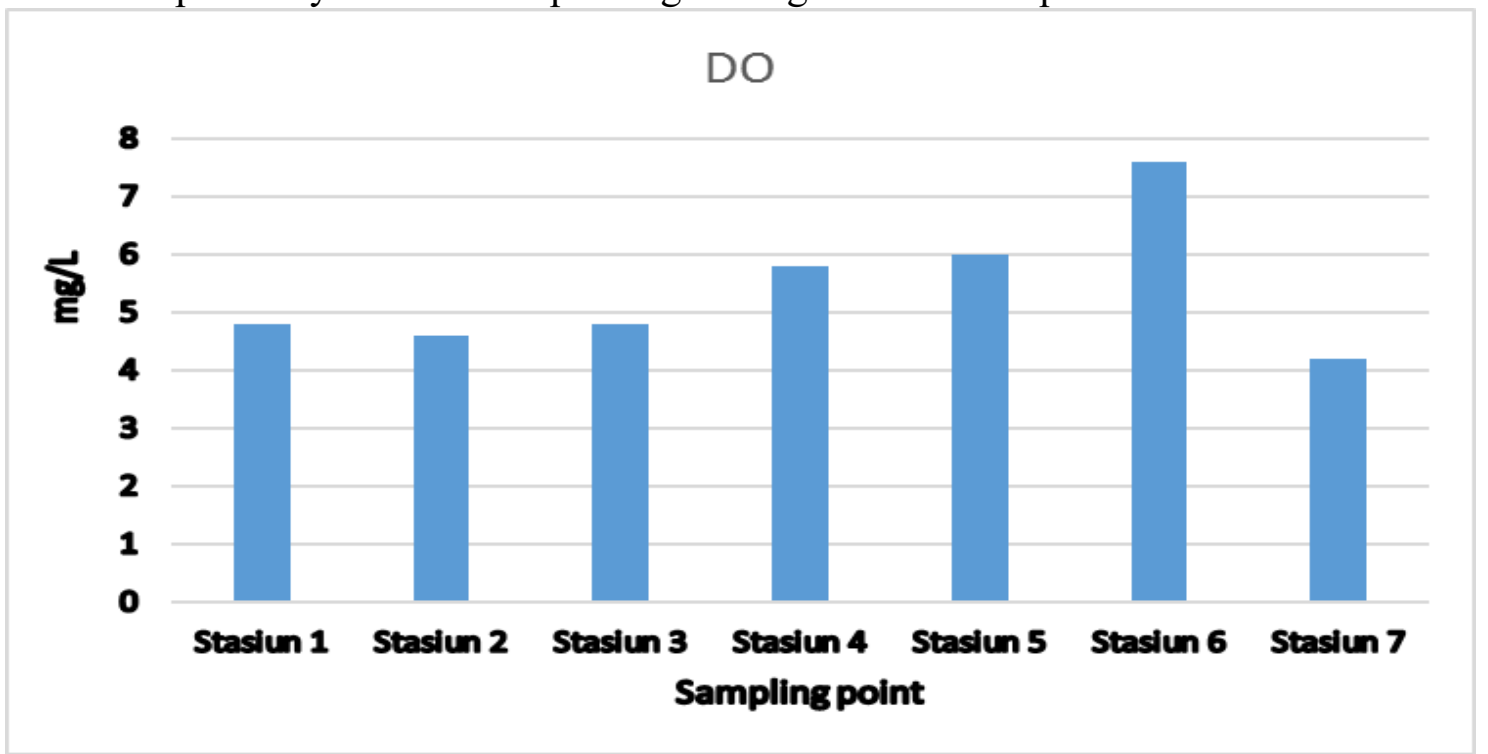

Gambar 5. Konsentrasi Oksigen terlarut (mg/L) di tujuh titik sampel di Sub DAS Kali Dendeng 
Biologycal Oxygen Demand (BOD) dan Chemical Oxygen Demand (COD)

Hasil pengukuran kadar BOD pada 7 titik sampel di Sub DAS Kali Dendeng menunjukkan bahwa konsentrasi BOD berada pada kisaran 1,5 - 6,3 $\mathrm{mg} / \mathrm{L}$ (Gambar 6). Konsentrasi BOD tertinggi berada pada air di Stasiun 3 yang disampling di lokasi Airnona sedangkan yang terendah berada pada Stasiun 7 yang disampling di Jembatan Bakunase. Hasil pengukuran ini menunjukkan bahwa sebagian besar air yang disampling konsentrasi BOD-nya telah melebihi ambang batas menurut PP. No 82 Tahun 2001 yaitu $3 \mathrm{mg} / \mathrm{L}$. Hasil temuan ini mengindikasikan bahwa air sungai pada Sub DAS Kali Dendeng telah mengalami pencemaran yang disebabkan oleh tingginya bahan organik. Agar kondisi ini tidak berlangsung terus menerus, maka perlu ada upaya sinergik dari pemerintah dan masyarakat untuk merehabiliatsi kondisi Sub DAS Kali Dendeng agar kembali tidak tercemar.

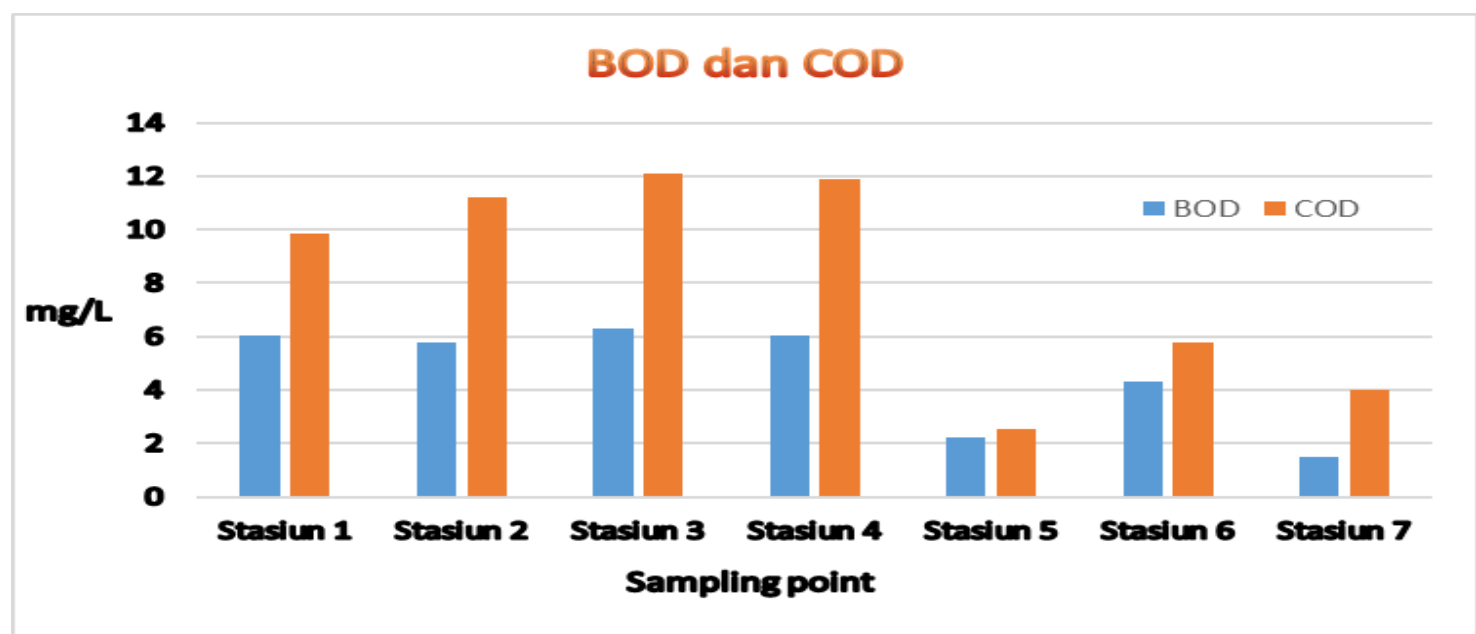

Gambar 6. Konsentrasi BOD dan COD (mg/L) di tujuh titik sampel di Sub DAS Kali Dendeng

Untuk COD, hasil pengukuran pada 7 stasiun yang berada pada Sub DAS Kali Dendeng menunjukkan bahwa konsentrasi COD berkisar antara 2,5 - 12,1 $\mathrm{mg} / \mathrm{L}$ seperti terlihat pada Gambar 6. Dengan demikian peraian Kali Dendeng diklasifikan masih layak digunakan untuk peruntukan air kelas II karena masih dibawah ambang batas yang ditetapkan yaitu $25 \mathrm{mg} / \mathrm{L}$.

\section{Nitrit}

Konsentrasi nitrit yang sampling pada 7 stasiun di Sub DAS Kali Dendeng berkisar antara 0,003 - 0,24 mg/L (Gambar 7). Konsentrasi ini masih dibawah baku mutu kelas II yang ditetapkan sesuai PP No. 82 Tahun 2001 yaitu 0,06 $\mathrm{mg} / \mathrm{L}$. Namun hasil pantauan yang dilakukan oleh Dinas Lingkungan Hidup Daerah selama periode 2014 - 2016 di enam lokasi menunjukkan bahwa pada tahun 2016 konsentrasi nitrit di sebagian besar loksi sampling telah melebihi ambang batas yang ditetapkan untuk air yang diperuntukan untuk prasarana/sarana rekreasi air, pembudidayaan ikan air tawar, peternakan, air untuk mengairi pertanaman, dan atau peruntukan lain yang mempersyaratkan mutu air yang sama dengan kegunaan tersebut;. Kondisi ini menjadi peringatan untuk 
berbagai pihak pemerintah dan stakeholder yang berada di sekitar Sub DAS Kali Dendeng.

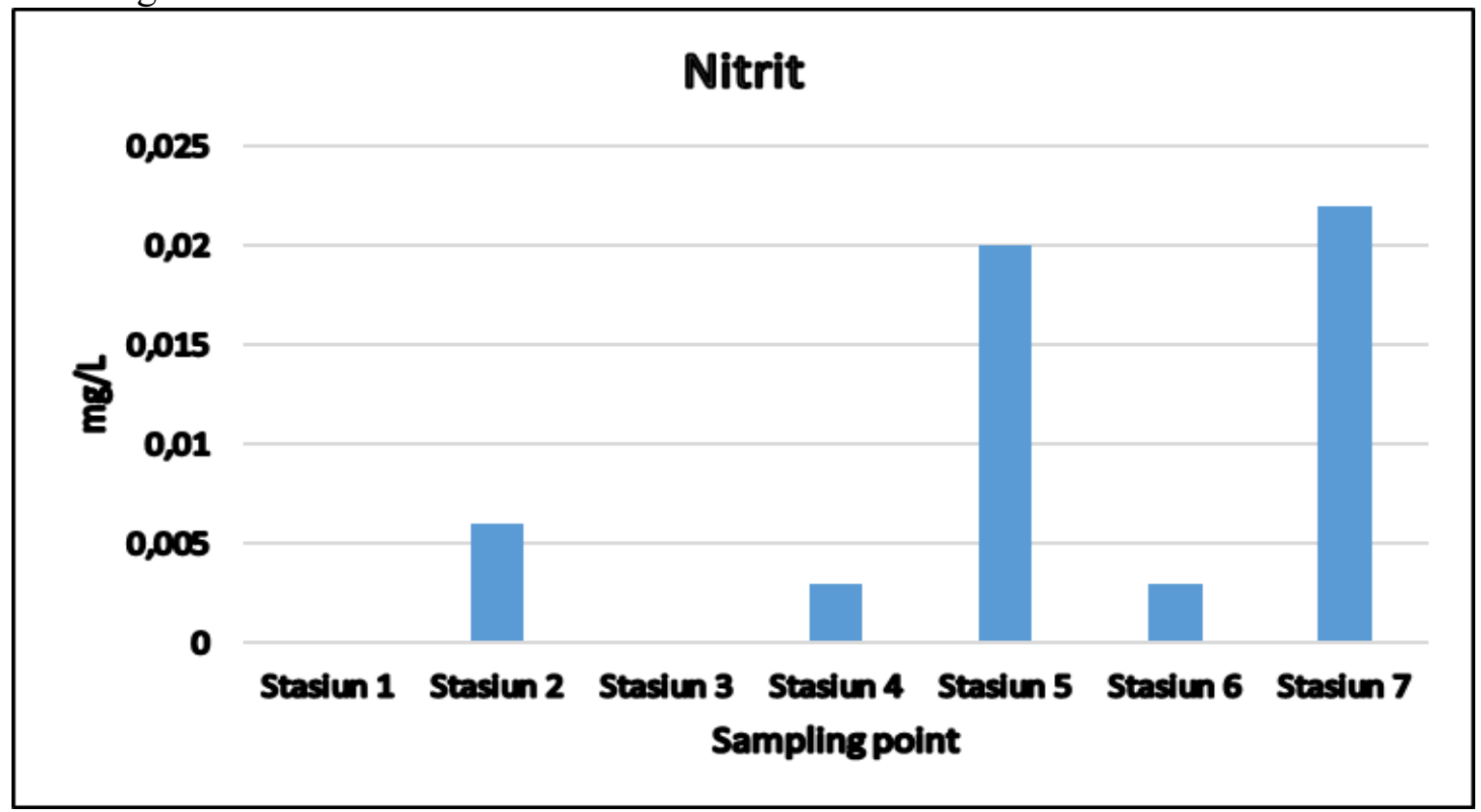

Gambar 7 Konsentrasi nitrit (mg/L) di tujuh titik sampel di Sub DAS Kali Dendeng

\section{Detergen}

Hasil analisa kadar detergen pada 7 titik sampel di Sub DAS Kali Dendeng mengindiksikan bahwa konsentrasi detergen $0-17 \mu \mathrm{g} / \mathrm{L}$ seperti tersaji pada Gambar 8. Konsentrasi tertinggi berada pada Stasiun 7 di Kali Bakunase sedangkan yang terendah di stasiun 1 di Kali Biknoi. Konsentrasi ini masih dibawah baku mutu yang ditetapkan menurut PP No. 82 Tahun 2001 yaitu 200 $\mu \mathrm{g} / \mathrm{L}$.

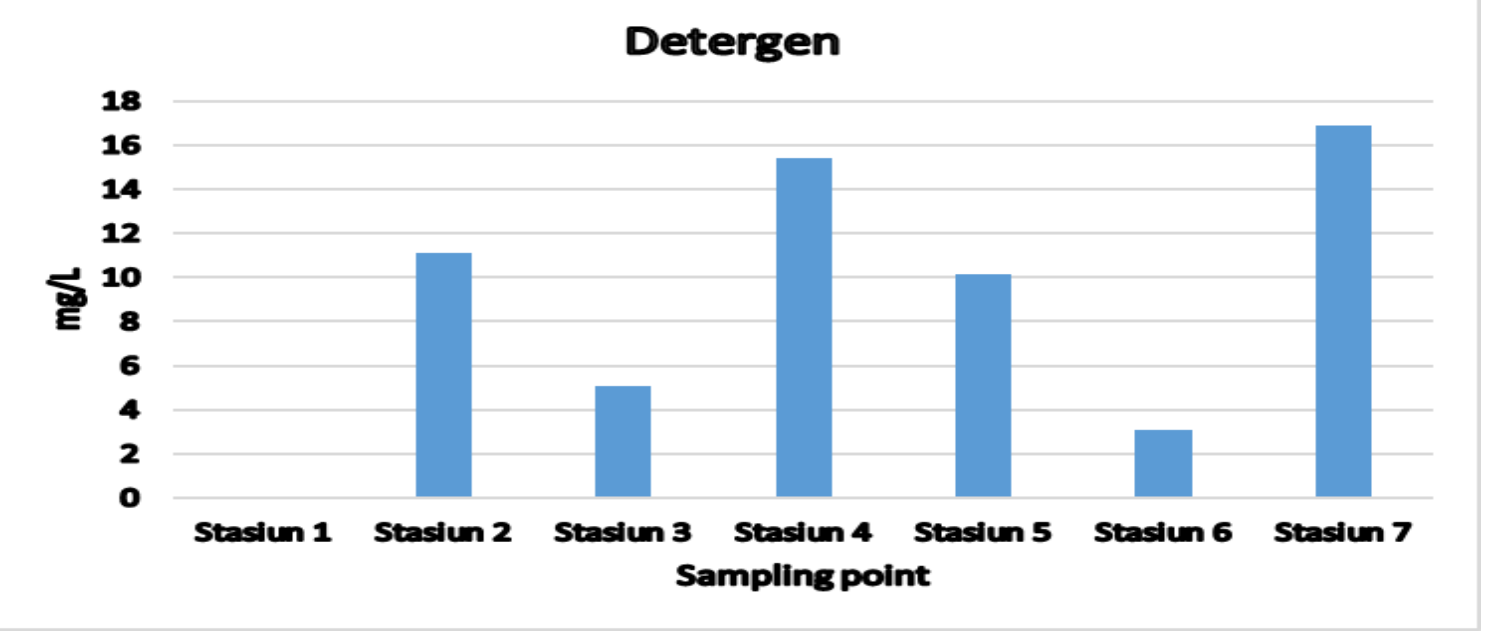

Gambar 8 Konsentrasi detergen (mg/L) di tujuh titik sampel di Sub DAS Kali Dendeng 


\section{Minyak dan Lemak}

Konsentrasi minyak dan lemak pada pada 7 titik sampel di Sub DAS Kali Dendeng berada pada kisaran $0-2000 \mu \mathrm{g} / \mathrm{L}$ seperti yang terlihat paga Gambar 9 . Konsentrasi tertinggi berada pada Stasiun 3 di Kali Sembunyi sedangkan yang terendah di Stasiun 6 di Bendungan Kali Dendeng. Untuk stasiun 2 dan 3 konsentrasinya sudah melebihi ambang baku mutu yang ditetapkan menurut PP No. 82 Tahun 2001 yaitu $1000 \mu \mathrm{g} / \mathrm{L}$.

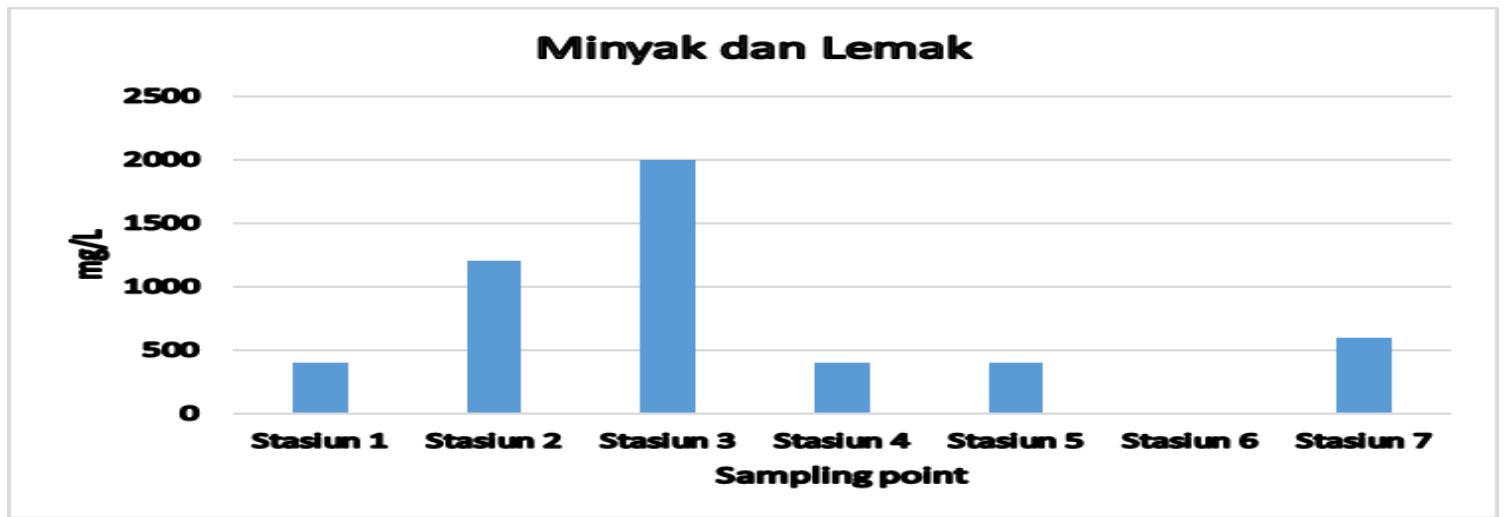

Gambar 9 Konsentrasi minyak dan lemak (mg/L) di tujuh titik sampel di sub DAS Kali Dendeng

\section{Coliform}

Analisis terhadap bakteri coliform pada 7 Stasiun yang disampling di Sub DAS Kali Dendeng menunjukkan bahwa konsentrasi faecal coliformnya berkisar antara $350-12.000 \mathrm{jml} / 100 \mathrm{ml}$ sedangkan untuk total coliformnya adalah $2.900-$ $12.000 \mathrm{jml} / 100 \mathrm{ml}$. Hasil pengukuran ini memperlihatkan bahwa sebagian besar air yang disampling bakteri coliformnya telah melebihi ambang batas menurut PP. No 82 Tahun 2001 yaitu $1000 \mathrm{jml} / 100 \mathrm{ml}$. Hasil ini mengindikasikan bahwa air sungai pada Sub DAS Kali Dendeng telah mengalami pencemaran yang disebabkan oleh tingginya bakteri pathogen. Hal ini perlu mendapat perhatian serius dari seluruh stakeholder.

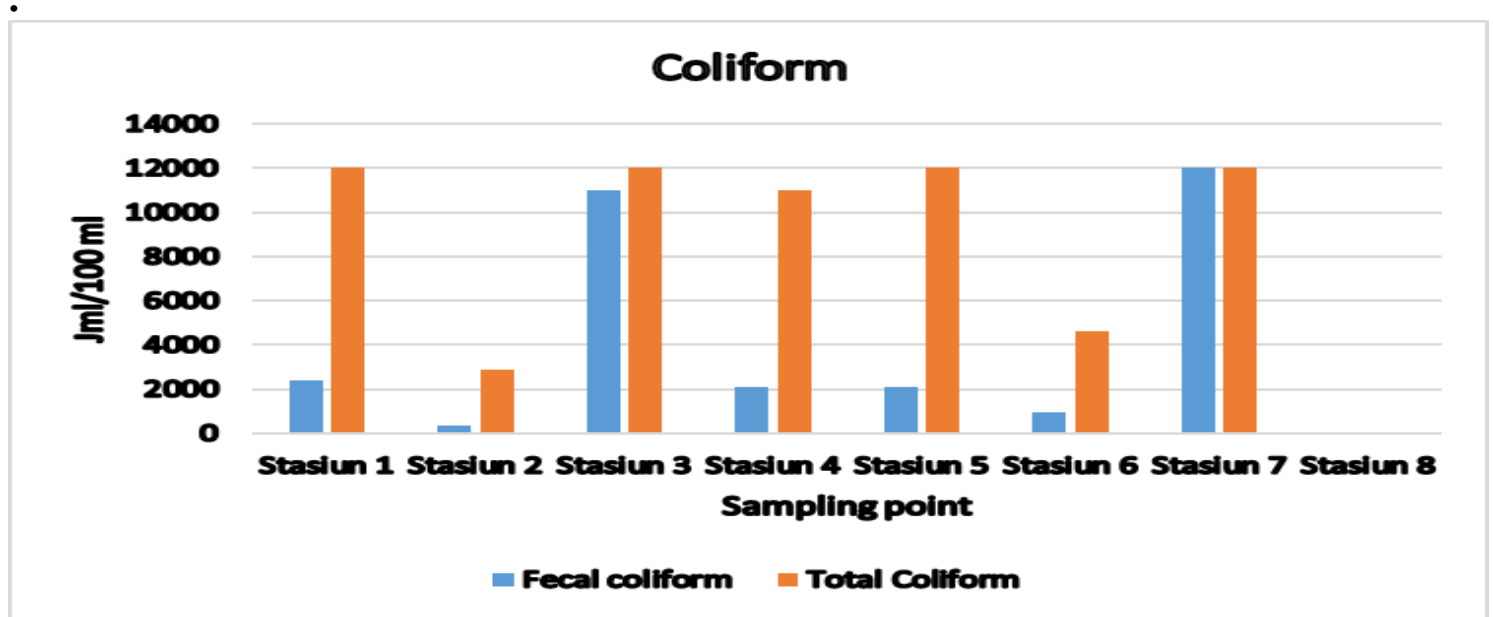

Gambar 10. Jumlah bakteri coliform $(\mathrm{Jml} / 100 \mathrm{ml})$ di tujuh titik sampel di sub DAS Kali Dendeng 
Analisa Status Kualitas Air di Sub DAS Kali Dendeng

Penentuan status kualitas air di Sub DAS Kali Dendeng menggunakan metode STORET. Indeks Storet dapat memberikan gambaran secara menyeluruh tentang kondisi umum kualitas airdi sub DAS Kali Dendeng. Dalam metode ini data parameter fisika dan kimia air hasil pengamatan dari nilai rata rata, maksiumum dan minimum dari setiap parameter dibandingkan dengan baku mutu air kelas II menurut PP No. 82 Tahun 2001. Nilai yang diperoleh diberikan skor sesuai dengan tingkat pencemarannya sehingga baik buruknya kualitas perairan dapat diketahui dengan melihat parameter-parameter apa saja yang tidak memenuhi baku mutu yang ditetapkan. Tabel 4.1 memeperlihatkan hasil evaluasi kualitas air di sub DAS Kali Dendeng dengan menggunakan metode STORET.

Tabel 3 Status Mutu Air Sub DAS Kali Dendeng Dengan Menggunakan Sistem Nilai STORET

\begin{tabular}{|c|c|c|c|c|c|c|}
\hline \multirow{2}{*}{ Parameter } & \multirow{2}{*}{ Unit } & \multirow{2}{*}{$\begin{array}{l}\text { Baku } \\
\text { mutu }\end{array}$} & \multicolumn{3}{|c|}{ Hasil Pengukuran } & \multirow{2}{*}{ Skor } \\
\hline & & & Max & Min & Average & \\
\hline $\mathrm{pH}$ & & $6-9$ & 7,9 & 7,1 & 7,47 & 0 \\
\hline TDS & $\mathrm{mg} / \mathrm{L}$ & 1000 & 333 & 189 & 248 & 0 \\
\hline DO & $\mathrm{mg} / \mathrm{L}$ & 4 & 7,6 & 4,2 & 5,39 & 0 \\
\hline BOD & $\mathrm{mg} / \mathrm{L}$ & 3 & 6,3 & 1,5 & 4,59 & -16 \\
\hline COD & $\mathrm{mg} / \mathrm{L}$ & 25 & 12,1 & 2,52 & 8,18 & 0 \\
\hline TSS & $\mathrm{mg} / \mathrm{L}$ & 50 & 15 & 1 & 7,14 & 0 \\
\hline $\mathrm{Cd}$ & $\mathrm{mg} / \mathrm{L}$ & 0,01 & 0,007 & 0,003 & 0,004 & 0 \\
\hline $\mathrm{Cu}$ & $\mathrm{mg} / \mathrm{L}$ & 0,02 & 0,008 & 0,001 & 0,005 & 0 \\
\hline $\mathrm{Zn}$ & $\mathrm{mg} / \mathrm{L}$ & 0,05 & 1,5 & 0,005 & 0,0096 & -4 \\
\hline Minyak dan Lemak & \multirow{2}{*}{$\begin{array}{l}\mu \mathrm{g} / \mathrm{L} \\
\mu \mathrm{g} / \mathrm{L}\end{array}$} & 1000 & 2000 & 0 & 714 & -4 \\
\hline Detergen & & 200 & 16,9 & 3,076 & 10,29 & 0 \\
\hline $\mathrm{PO}_{4}$ & $\mathrm{mg} / \mathrm{L}$ & 0,2 & 0,001 & 0,001 & 0,001 & 0 \\
\hline $\mathrm{NO}_{2}$ & $\mathrm{mg} / \mathrm{L}$ & 0,06 & 0,024 & 0,003 & 0,011 & 0 \\
\hline \multicolumn{6}{|c|}{ Jumlah skor } & -24 \\
\hline
\end{tabular}

Tabel 3 memperlihatkan bahwa kondisi kualitas air di sub DAS Kali Dendeng yang terkategoi sebagai kelas II yang dapat digunakan untuk prasarana/sarana rekreasi air, pembudidayaan ikan air tawar, peternakan, air untuk mengairi pertanaman, dan atau peruntukan lain yang mempersyaratkan mutu air yang sama dengan kegunaan tersebut termasuk dalam kondisi sedang dan diklasifikasikan tercemar sedang dengan nilai indeks STORET -24. Berdasarkan hasil menggunakan metode STORET terlihat bahwa kontribusi terbesar pada pencemaran di sub DAS Kali Dendeng adalah parameter BOD.

\subsection{Beban Pencemar}

Beban pencemaran adalah jumlah suatu unsur pencemar yang terkandung dalam air atau air limbah. Beban pencemaran di Sub DAS Kali Dendeng bersumber dari limbah domestik, limbah industri kecil, limbah peternakan. Sumber pencemar utama di Sub DAS Kali Dendeng berasal dari limbah domestik 
yakni dari masyarakat yang tinggal di sepanjang Kali Dendeng, sampah, dan detergen dan juga limbah industri kecil seperti industri tahu/tempe yang berada di sekitar bantaran Kali Dendeng. Perhitungan beban pencemaran dari limbah domestik yang dibuang ke sub DAS Kali Dendeng, didasarkan atas hasil kuesioner pembuangan air limbah rumah tangga di sepanjang sisi kiri-kanan Kali Dendeng dan jumlah penduduk yang bermukim dalam zona lebih kurang 500 meter dari Kali Dendeng. Berdasarkan data hasil olahan dari BALITBANGDA Kota Kupang jumlah penduduk yang tinggal dalam zona sekitar 500 meter dari Kali Dendeng adalah 1851 orang. Data ini menunjukkan bahwa sebanyak 63,6\% (42 responden) membuang air limbah domestik langsung ke sungai dan ke tanah terbuka tanpa melalui pengolahan. Dengan demikian, persentase pembuangan limbah domestik ke Sub DAS Kali Dendeng ini yang dipakai untuk perhitungan adalah 63,6\% dari jumlah penduduk di sempadan sungai Sub DAS Kali Dendeng. Jumlah pemakaian air yang digunakan adalah 60 liter/orang/hari, sedangkan jumlah air buangan adalah $80 \%$ pemakaian air. Beban pencemaran di Sub DAS Kali Dendeng bersumber limbah domestik untuk parameter pencemar BOD dan COD adalah 29, $448 \mathrm{~kg} / \mathrm{hari}$ dan 56, $540 \mathrm{~kg} /$ hari.. Beban pencemaran BOD dan COD di atas baru bersumber dari limbah domestik. Beban pencemar yang berasal dari industri kecil dan peternakan tidak dapat dihitung karena tidak tersedianya data yang akurat tentang jumlah industri kecil dan peternak yang tinggal di kali Dendeng.

\section{Peran Pemerintah dan Masyarakat Dalam Mewujudkan Keberlajutan Pemanfaatan, Pengelolaan dan Perlindungan Terhadap Sumberdaya Air di Kali Dendeng}

Pemanfaatan sumberdaya air di Sub DAS Kali Dendeng Kota Kupang harus dikelola secara menyeluruh. Untuk itu perlu dilihat secara keseluruhan visi, misi dan program Pemerintah Kota Kupang dalam rangka mewujudkan keberlanjutan pemanfaatan, pengelolaan dan perlindungan terhadap sumberdaya alam dimana salah satunya adalah Kali Dendeng.

Visi Pemerintah Kota Kupang 2018 - 2022 adalah" Terwujudnya Kota Kupang yang Layak Huni Cerdas, Mandiri, dan Sejahtera dengan Tata Kelola Bebas KKN". Yang dimaksud dengan kota layak huni adalah kota yang ketersediaan sarana dan prasarana perkotaan seperti air minum yang menjangkau seluruh penduduk, listrik yang cukup bagi kebutuhan penduduk dan transportasi yang aman bagi warga. Selain itu salah satu misi yang dikembangkan di Kota Kupang adalah mempersiapkan Kota Kupang menuju metropolitan yang berwawasan lingkungan. Untuk tujuan tersebut maka Pemerintah Kota Kupang bertekad untuk mewujudkan kuantitas dan kualitas udara, air dan tanah sesuai dengan baku mutu lingkungan. Dengan fokus utama adalah:

1. Terpenuhinya kebutuhan air baku bagi warga kota dengan cakupan $100 \%$ pada tahun 2020

2. Terbangunnya jebakan-jebakan air dan sumur resapan pada setiap rumah penduduk.

3. Menjaga kelestarian atau ketersediaan daerah konservasi, dan 
4. Mempertahankan ruang terbuka hijau sebanyak 30\% dari luas wilayah Kota Kupang.

Misi ini selaras dengan tujuan penyelamatan sumberdaya air yang sangat penting di Kupang yaitu Sub DAS Kali Dendeng yang merupakan satu diantara 35 sungai penting di Indonesia. Sub DAS Kali Dendeng melewati 12 Kelurahan dan sumberdaya air ini digunakan untuk mensuplai air bersih yang diperoleh masyarakat Kota Kupang dan juga untuk keperluan lainnya. Oleh karena itu penyelamatan sumber daya air melalui pengendalian pencemaran air pada Sub DAS Kali Dendeng selaras dengan misi Pemerintah daerah setempat dalam rangka mempersiapkan Kota Kupang menuju metropolitan yang berwawasan lingkungan.

Daerah Aliran Sungai (DAS) Kali Dendeng merupakan salah satu sumberdaya alam yang perlu dilestarikan keberadaannya. Menginngat pentingnya Sub DAS Kali Dendeng bagi masyarakat Kota Kupang, maka kebijakan pengelolaan sumberdaya air harus dilakukan secara menyeluruh. Oleh karena itu perlu dibuat peraturan daerah yang mengatur tentang kebijakan sumberdaya air yang terintegrasi agar masyarakat dapat menikmati sumberdaya air secara adil. Peraturan yang telah tebuat perlu dilaksanakan secara konsekuen dengan memperhatikan kesetaraan dan keadilan.

Untuk mewujudkan kondisi tersebut, maka pemerintah daerah dan warga perlu bekerjasama. Kali Dendeng merupakan salah satu sumberdaya air yang sangat produktif. Agar pengelolaannya lebih bermanfaat maka pelu dilakukan secara terintegrasi. Untuk itu seluruh organisasi pemerintah daerah yang terkait kerja dengan sub DAS Kali Dendeng perlu berdialog dan bekerjasama agar tidak terjadi tumpang tindih kewenangan dan pekerjaan. Selain itu pola kolaborasi antar instasi perlu ditingkatkan agar tujuan untuk pengelolaan sub DAS Kali Dendeng yang berkelanjutan dapat terwujud.

Pengelolaan sumberdaya air di Sub DAS Kali Dendeng perlu melibatkan seluruh stakeholder secara terpadu dan menyeluruh dari proses perencanaan, pelaksanaan dan pemantauan. Selain itu pengelolaan sumberdaya air di Sub DAS Kali Dendeng perlu memperhatikan sisi konservasi sumberdaya air, pendayagunaan sumberdaya air dan pengendalian daya rusak air. Kebijakan pengelolaan sumberdaya air di Sub DAS Kali Dendeng harus mencakup pertama; pengelolaan sumberdaya air untuk kemanfaatan masyarakat masa kini dan generasi masa mendatang. Kedua; peningkatan konservasi sumber daya air secara terus menerus. Pengolahan air untuk kemanfaatan kebutuhan manusia masa kini dan masa depan menuntut perlu ada keberlanjutan ekologi sungai, sumber-sumber mata air dan ekosistemnya. Dalam konteks ini, kebijakan konservasi lingkungan kawasan di Sub DAS Kali Dendeng perlu memperhatikan keanekaragaman hayati, dan perubahan iklim, agar keberlanjutan dan ketersediaan sumberdaya air di Kali Dendeng dari segi kuantitas dan kualitas tetap memadai untuk memenuhi kebutuhan manusia, masa kini dan masa depan. Ketiga; kebijakan pendayagunaan sumberdaya air di Sub DAS Kali Dendeng harus memenuhi unsur unsur keadilan dan kesejahteraan masyarakat artinya pengelolaan sumberdaya air harus memenuhi social justice yakni memenuhi kebutuhan masyarakat secara adil tanpa membeda-bedakan derajat sosial masyarakat. Kebijakan pengelolaan air secara adil ini terkait juga dengan alokasi secara proporsional kebutuhan peruntukan 
penggunaan air seperti: keperluan domestik, pertanian, perikanan, peternakan, industri, dan kebutuhan perkotaan. Keempat; kebijakan pengelolaan Sub DAS Kali Dendeng perlu mempertahankan keaslian daerah hulu sungai dan lingkungan ekosistemnya agar dapat mencegah terjadinya banjir, erosi, sedimentasi, patahan tanah-tebing yang merupakan faktor-faktor daya rusak air. Kebijakan ini sekaligus mencegah munculnya dampak penurunan kualitas tanah dan air, sebagai akibat yang timbul banjir, erosi, dan sedimentasi. Kelima; kebijakan pengelolaan suberdaya air di Sub DAS Kali Dendeng perlu melibatkan masyarakat dan dunia usaha terutama dalam pengelolaan sumberdaya air dan dalam mengatasi kerusakan ekosistem yang ada. Peran aktif masayarakat dalam konteks ini diharapkan dapat mengantisipasi terjadinya banjir dan erosi melalui penataan dan pemeliharaan lingkungan sungai dan ekosistemnya. Keenam; kebijakan pengembangan jaringan sistem informasi sumberdaya air (SISDA) dalam kerangka pengelolaan sumberdaya air nasional terpadu antar sektor (Toni, 2010).

\section{KESIMPULAN}

Berdasarkan kajian ini maka dapat disimpulkan bahwa kadar BOD, minyak dan lemak, dan coliform di sub DAS Kali Dendeng telah melebihi ambang batas yang ditetapkan. Analisa status kualitas air dengan mengunakan model STORET menunjukkan bahwa sub DAS Kali Dendeng dikategorikan tercemar sedang. Beban pencemar BOD dan COD berturut turut adalah $29,448 \mathrm{~kg}$ /hari dan 56,540 $\mathrm{kg}$ /hari. Sumber pencemar umumnya berasal dari sampah, limbah cair buangan baik dari septik maupun greywater, buangan limbah industri tahu, dan limbah pertenakan (babi). Belum adanya kesadaran masyarakat dalam melestarikan sumberdaya air di sub DAS Kali Dendeng Hal ini disebabkan karena rendahnya pengetahuan tentang peraturan lingkungan hidup yang berlaku dan akses ke sungai yang sangat mudah karena tidak adanya saluran yang memadai. Pengusaha industri kecil dan peternakan yang berada di Sub DAS Kali Dendeng, sebagian besar limbahnya dibuang tanpa diolah terlebih dahulu karena mahalnya biaya treatment air limbah. Umumnya industri kecil yang ada mempunyai keterbatasan dana. Koordinasi antar berbagai stakeholder belum berjalan sesuai dengan yang diharapkan. Hal ini disebabkan karena tumpang tindihnya kewenangan yang ada di tiap OPD. Oleh karena itu, seluruh stakeholder perlu duduk bersama untuk berdikusi agar pola kolaborasi antar instansi perlu dioptimalkan guna mewujudkan pengelolaan Sub DAS Kali Dendeng yang berkelanjutan.

\section{Daftar Pustaka}

[APHA] American Public Health Association. 1998. Standart Method for the Examination of Water and Waste Water. 20 ${ }^{\mathrm{ed}}$. Washington: American Public Health Association, American Water Works Association, and Water Pollution Control Federation.

BAPEDALDA PROVINSI NTT 2005. Laporan Akhir Kualitas Air Sungai Dendeng, 2006 Nusa TenggaraTimur, Kupang, Badan Pengendalian Dampak Lingkungan Provinsi. 
BPS-KOTA-KUPANG 2017. Statistik Daerah Kota Kupang 2015, Kupang , Badan Pusat Statistik.

KANSIIME, F. \& NALUBEGA, M. 1999. Wastewater treatment by a natural wetland: the Nakivubo swamp, Uganda, CRC Press.

KIVAISI, A. K. 2001. The potential for constructed wetlands for wastewater treatment and reuse in developing countries: a review. Ecological Engineering, 16, 545-560.

[KLH] KEMENTERIAN NEGARA LINGKUNGAN HIDUP. 2009. Status Lingkungan Hidup Indonesia 2008. Jakarta: Penerbit Kementerian Negara Lingkungan Hidup.

KURNIADIE, D. 2011. Wastewater treatment using vertical subsurface flow constructed wetland in Indonesia. American Journal of Environmental Sciences, 7 (1), 15 - 19.

Peraturan Pemerintah Nomor 82 Tahun 2001 tentang Pengelolaan Kualitas Air dan Pengendalian Pencemaran Air, Jakarta.

USAID 2006. Comparative Study Centralized Wastewater Treatment Plants in Indonesia., Jakarta, USAID Indonesia 